\title{
The engineer as judge: engineering analysis and political economy in eighteenth century France
}

\section{Citation}

Picon, Antoine. 2009. “The Engineer as Judge: Engineering Analysis and Political Economy in Eighteenth Century France." Engineering Studies 1 (1) (March): 19-34. doi:10.1080/19378620902725174.

\section{Published Version}

10.1080/19378620902725174

\section{Permanent link}

http://nrs.harvard.edu/urn-3:HUL.InstRepos:37093466

\section{Terms of Use}

This article was downloaded from Harvard University's DASH repository, and is made available under the terms and conditions applicable to Other Posted Material, as set forth at http:// nrs.harvard.edu/urn-3:HUL.InstRepos:dash.current.terms-of-use\#LAA

\section{Share Your Story}

The Harvard community has made this article openly available.

Please share how this access benefits you. Submit a story.

\section{Accessibility}




\title{
FROM FAITH IN NUMBERS TO EXPERIMENT
}

\section{EIGHTEENTH-CENTURY FRENCH ENGINEERS AND CALCULATION}

\author{
Antoine Picon \\ Harvard University Graduate School of Design, Cambridge, MA \\ Ecole nationale des Ponts et Chaussées, Paris
}

\section{ENGINEERS AND CALCULATION: A MATTER OF EFFICIENCY}

The eighteenth century represented clearly a major turning point in the French engineers' practices of calculation. This turning point is often characterized by contemporary historians of science and technology as the beginning of a process of "mathematisation", a process that can be observed on two different levels at least. The first one corresponds to the massive introduction of figures in the technological fields covered by engineers. Throughout the eighteenth century, impressive amounts of data were collected on topics such as the strength of materials or water flow. On another level, engineering theoretical knowledge evolved. From the theory of vaults to applied hydrodynamics, new models, new mathematical techniques emerged, bearing close relation with the general scientific progress of the century. In the mid 1790's, the relation between science and engineering was considered as self-evident enough to justify the creation of the Ecole polytechnique. 
A turning point is not necessarily a complete revolution. Quantification practices were already quite developed among seventeenth-century French engineers. At the time of Vauban, Fortification engineers in particular had acquired a thorough empirical knowledge of subjects such as the earth pressure or the resistance of masonry to cannonball. Besides, engineers often used sophisticated geometrical methods in their designs. As far as technology is concerned, the "mathematisation" process of the Enlightenment period was not so radical a change as it may appear at first glance.

This impression of something entirely new occurring in the eighteenth-century is partly the result of our retrospective knowledge of what happened during the first decades of the following century. Quantification then became a common engineering practice, while disciplines such as strength of materials or applied hydrodynamics developed at a smart pace. The eighteenth-century relation between engineering and calculation was on the other hand far more complex. New quantified data and theoretical models found indeed their counterpart in the permanence of very traditional attitudes. Furthermore, their use raised questions, even among the most innovative members of the profession.

To be aware of the dangers of retrospective evaluation does not mean however that one has to minimize the importance of the eighteenth-century turning-point. It must rather be an incentive to take seriously into account its somewhat contradictory features. Some of its discrepancies were related to the everlasting conflict between tradition and change, but others were linked to the internal tensions of the French Enlightenment. In their trend towards quantification and calculation, engineers were part of a larger movement that concerned administrators as well as scientists. As historians such as Charles Coulston Gillispie or Jean-Claude Perrot have shown, the 
State played a major role in the initiatives taken by those different actors ${ }^{1}$. To a certain extent, the changes that occurred in engineering were the consequence of the French engineers civil servant status.

Although part of a general movement, engineers retained a marked specificity. This specificity can be approached by distinguishing between objectivity and efficiency. Even if those two ideals, or rather those two social constructions ${ }^{2}$, are closely related, they differ in some ways. Rooted in the desire for truth, objectivity puts the emphasis on the research of natural regularities or laws, laws that are often supposed to apply to society, to enable its description and to provide directions for its regeneration. Efficiency, on the other hand, deals primarily with the use of nature by society. Truth then becomes a secondary problem, the main preoccupation being to promote a mutual adaptation between the natural and the social orders.

In Eighteenth-century French culture, objectivity and efficiency were especially close one to another. The widespread notion of utility was precisely located at their intersection. "Utility encircles everything," wrote Diderot in his Pensées sur l'interprétation de la nature ${ }^{3}$. But in spite of the Encyclopedist's keen interest for technology, the utility he had in mind was not identical to the one engineers were pursuing. In their attempts to use science as a tool for administrative and manufacturing rationalization, Condorcet or Lavoisier differed also from the

1 C.-C. Gillispie, Science and polity in France at the end of the Old Regime, Princeton, Princeton University Press, 1980; J.-C. Perrot, Genèse d'une ville moderne Caen au XVIII e siècle, Paris, La Haye, Mouton, 1975; J.-C. Perrot, Une Histoire intellectuelle de l'économie politique, Paris, Ecole des hautes études en sciences sociales, 1992.

2 They are of course no more eternal principles of efficiency than intemporal laws and methods governing objectivity.:=//+

${ }^{3}$ D. Diderot, Pensées sur l'interprétation de la nature, 1754, p. 23. 
engineers' perspective. For the philosophers or the scientists, the true laws of nature were to reshape society, to guide the steps taken towards its regeneration. For the engineers, regeneration was to be achieved trough a more tortuous route. Once again, efficiency was a matter of mutual adaptation rather than a one way patterning.

Calculation has not the same scope depending on whether the aim is objectivity or efficiency. Data and mathematical tools are considered in a more instrumental way in the second case than in the first. It is well know that the first quality of an engineering formula is to work rather than to be scientifically accurate. Besides, the history of objectivity is not exactly the same as the history of efficiency, though their lines often intersect. This paper intends to be mainly a contribution to the latter.

\section{FAITH IN NUMBERS: PROPORTION IN THE CLASSICAL AGE}

To characterize the eighteenth-century turning point, it is necessary to evoke how calculation was considered by the engineers of the Classical Age. As I have said, those engineers already counted and measured; they used rather complex geometrical methods in their designs. Engineering data and design methods were already quite diverse at the time. In spite of the strong connections they maintained, the art of the Fortification engineer was different from the techniques of the ordinary builder. The various fields of engineering remained nevertheless united by a common reference to proportion. Personal experience and empirical measurements acquired a truly universal meaning through their translation into the vocabulary of proportion. The bridge builder knew for instance that the piers width had to be comprised between one sixth and one forth of the total span of the arch. Machine design used the same kind of recipes, recipes that bore some analogy to the Vitruvian principles of 
modularity at work in architectural theory and practice ${ }^{4}$. Such an analogy could still be observed in Bélidor's Architecture hydraulique, published for the first time in 1737-1739. In order to describe the locks, the famous engineer explained that "imitating the architects who divide the diameter of a column in a certain number of equal parts in order to express the dimensions of every single feature of the order", he had "divided the width of the locks in twelve modules to fix theirs 5 ."

To be fully understood, the engineer's reference to proportion and modularity must be placed back into the context of a widespread belief in a world created by God according to architectonic principles. This belief in an architectonic world was for instance expressed by Bossuet in his Introduction à la philosophie ${ }^{6}$. It explained the success achieved by the various inquiries concerning the proportions given to the Temple of Jerusalem that were conducted and published throughout the sixteenth and seventeenth century ${ }^{7}$. The most famous of them, Jesuit Villalpandus' commentary of Ezechiel, was read by numerous architects and engineers. Inspired by the divinity, the proportions of the Temple were supposed to convey an elaborate knowledge. In a way, the proportions used by architects and engineers in their everyday tasks were derivatives of those employed by God. Without referring to Villalpandus, members of both professions knew for certain that architectural and technological proportions were natural, just as the rules of musical harmony.

4 On the Vitruvian architectural tradition, see for instance H.-W. Kruft, Geschichte der Architekturtheorie. Von der Antike bis zum Gegenwart, Munich, C.-H. Beck, 1985; G. Germann, Vitruve et le vitruvianisme. Introduction à l'histoire de la théorie architecturale, Darmstadt, 1987, French translation Lausanne, Presses Polytechniques et Universitaires Romandes, 1991.

5 B. Forest de Bélidor, Architecture hydraulique, Paris, 1737-1739, new edition Paris, F. Didot, 1810, t. 3, p. V.

6 J.-B. Bossuet, Introduction à la philosophie, ou de la connaissance de Dieu, et de soi-mesme, Paris, R.-M. d'Espilly, 1722.

7 See J. Rykwert, La Maison d'Adam au paradis, Chicago, New-York, 1972, trad. fr. Paris, Le Seuil, 1976. 
Working most of the time for princes and lords, architects and engineers were often tempted to turn their architectonic vision of the natural world into a justification of the hierarchic social order that surrounded them. Such a temptation explained some decisive features of the French classical architecture, with its programmatic and ornamental gradations which were clearly intended to reflect the stratification of social dignities. At the end of the seventeenth century, "convenance" became the key word to denote the appropriate relation that was to observed between the architectural treatment and the rank of the owner of a building 8 . At the time, the "convenance" principle applied also to engineering. Through their proportions and a generally sober ornamentation, major engineering works had to express their programmatic as well as symbolic function.

A belief somewhat religious hardly plays its role if it does not allow for the complexity of ordinary life and the necessary adaptations it requires. While taking proportions for natural and immutable, engineers as well as architects did not hesitate a second to alter them in order to cope with practical problems. While calculation was synonymous with a virtuoso handling of modular dimensions on a theoretical ground, it was rather a matter of simple and sometimes radical modifications made to the rules in practice. Although he had a fervent faith in proportions, the architect and engineer François Blondel summarized well this attitude at the beginning of one of his treatises : "In a word, one cannot say that in the arts, mere knowledge of the principles is enough sufficient to bring them to perfection. One must apply them, and this application always reveals the resistance and the tenacity of matter. A thousand

8 Cf. W. Szambien, Symétrie goût caractère. Théorie et terminologie de l'architecture à l'âge classique 1500-1800, Paris, Picard, 1986. 
obstacles rise, obstacles that one can discover and overcome only with the help of practice and experience 9 ."

Such an attitude meant that architectural and engineering theory was not necessarily accurate in the modern sense of the word. It provided the designer with a broad canvass that had to be adapted to practical situations, often at the price of major modifications. During the seventeenth-century, this rather permissive conception of the relation between theory and practice was not often challenged, though science had already begun to give the example of a more demanding one. Significantly enough, the main criticisms addressed to the use of proportion were made by architects or engineers who were at the same time scientists. Simon Stevin in the Netherlands, Christopher Wren in England and Claude Perrault in France, declared themselves convinced of the purely artificial origin of proportions 10 . Their position announced what was to become one of the major technological issues of the eighteenth century, the definition of a new frame for engineering calculation.

\section{TRADITION, EXPERIMENT AND CALCULATION}

The new engineering practices that emerged during the Enlightenment must not hide the fact that tradition remained predominant throughout the period. In the first French engineering schools such as the Ecole des Ponts et Chaussées, founded in 1747, or the Ecole du Génie de Mézières, created in 1748, students continued to learn the

\footnotetext{
${ }^{9}$ F. Blondel, L'Art de jetter les bombes, Paris, l'auteur et N. Langlois, 1683.

10 See C. van den Heuvel, "Stevin et Ramus. Méthodes d'architecture militaire et civile en bois", in Actes du colloque international sur les plans-reliefs au passé et au présent, Paris, C.D.U., S.E.D.E.S., 1993, pp. 57-70; J.-A. Bennett, The Mathematical science of Christopher Wren, Cambridge, Cambridge University Press, 1982; A. Picon, Claude Perrault (1613-1688) ou la curiosité d'un classique, Paris, Picard, 1988.
} 
principles of architecture 11 . The weight of tradition was especially pronounced at the Ecole des Ponts. The training it gave was based on the traditional techniques of design rather than on new scientific methods. At the end of the century, most engineers had remained "artists" in the old sense, that is to say professionals much closer to architects than to scientists 12 .

Given that traditional background, one is nevertheless struck by the multiplication of experiments conducted by eighteenth-century engineers. Many of those experiments concerned strength of materials. The founder and first director of the Ecole des Ponts et Chaussées, Jean-Rodolphe Perronet, studied for instance the resistance of stone to compression. The same type of investigation was carried on later by his former student Emiland-Marie Gauthey 13. Other Ponts et Chaussées engineers such as Joseph Lamblardie or Pierre Simon Girard concentrated on the mechanical properties of wood and iron. At the end of the century, the latter was to publish a treatise on the strength of materials partly based on his experiments 14 .

More complex problems were tackled by the Fortification engineer Charles-Augustin Coulomb. Prior to the composition of his famous "Essai sur une application des règles de maximis et minimis à quelques problèmes de statique relatifs à l'architecture", Coulomb conducted a succession of experiments on earth pressure and vault

11 Cf. B. Belhoste, A. Picon, J. Sakarovitch, "Les exercices dans les écoles d'ingénieurs sous l'Ancien Régime et la Révolution", in Histoire de l'éducation, n 46, 1990, pp. 53-109.

12 On the Ecole des Ponts et Chaussées, see A. Picon, L'Invention de l'ingénieur moderne. L'Ecole des Ponts et Chaussées 1757-1851, Paris, Presses de l'Ecole nationale des Ponts et Chaussées, 1992.

13 A comprehensive survey of eighteenth-century experiments in the field of strength of materials is given in J.-A. Borgnis, Traité complet de mécanique appliquée aux arts, Paris, Bachelier, 1818.

14 P.-S. Girard, Traité analytique de la résistance des solides, et des solides d'égale résistance, Paris, F. Didot, Dupont, 1798. 
mechanism of ruin ${ }^{15}$. His colleague Pierre-Georges Dubuat studied water flow at the Ecole du Génie de Mézières. The results he obtained enabled him to publish his Principes d'hydraulique in 1779. The book contained among others an elaborate formula giving the speed of the flow in a canal as an expression of the slope, of the surface of the section and of the wet perimeter of the latter. Five years before, the Ponts et Chaussées engineer Antoine Chézy had obtained a very similar experimental result, although more simple 16 .

Eighteenth-century engineers also studied machines. At the beginning of his career, Perronet made for instance a thorough survey of a pin factory in Normandy, designing with accuracy the various machines employed and inquiring about their productivity 17. Years later Coulomb was to investigate mechanical topics ranging from the friction of rope to the output of various windmills 18 . The study of friction which had been for a long time neglected by engineers because of its complexity was typical of the new technological curiosity that was developing at the time.

This curiosity extended to human labor, to the mechanical power it represented as well as to the phenomenon of fatigue. At the intersection of mechanics and a sort of proto-ergonomics, Coulomb made experiments on the various ways men exerted their forces in their daily labor. In a remarkable memoir published at the end of the century,

15 On Coulomb's experiments and theory, see C.-S. Gillmor, Coulomb and the evolution of physics and engineering in eighteenth-century France, Princeton, Princeton University Press, 1971.

16 Cf. G. Mouret, "Antoine Chézy Histoire d'une formule d'hydraulique", in Annales des Ponts et Chaussées, 2 e trimestre 1921, pp. 165-269.

17 J.-R. Perronet, Explication de la façon dont on réduit le fil de laiton à différentes grosseurs dans la ville de Laigle, 1739, manuscript of the Ecole nationale des Ponts et Chaussées, Ms 2383; J.-R. Perronet, Description de la façon dont on fait les épingles à Laigle en Normandie, 1740, manuscript of the Ecole nationale des Ponts et Chaussées, Ms 2385. Some of the drawings made by Perronet on this occasion were later used in the Encyclopédie. 
he defined work as the product of thrust multiplied by the speed and the length of time of the effort exerted. Having observed that the respective importance of these factors had a direct influence on the worker's fatigue, he applied his favorite mathematical method, the maximis and minimis calculation, to various types of efforts, from the transport of a load on a horizontal ground to the driving of a bridge pile 19 .

The well-known achievements of Coulomb must not give the impression that all the experiments conducted by the eighteenth-century engineers were as rigorously conducted as his. Neither must it convey the idea that experience necessarily lead up to new theories. Far from it, most experiments provided data that did not fit well into any theoretical frame. In this context, the advocates of tradition could easily ignore results that seemed of no real consequence. Experimentalists themselves had their doubts because of unsolved methodological questions such as the influence of shape or scale on experiments regarding the strength of materials or the stability of structures. If experiment was useful, it was rather more for the supplementary intuition it gave to the experimentalist than for its predictive power. His most immediate effect, was to challenge the traditional engineering knowledge expressed in terms of proportions.

When they did use the results of their experiments, engineers nevertheless often combined them with existing theories, since no other frame was at their disposal. Perronet for example built his major bridges according to principles contradictory

\footnotetext{
18 C.-A. Coulomb, Théorie des machines simples, en ayant égard au frottement de leurs parties et à la roideur des cordages, Paris, Bachelier, 1821.

19 C.-A. Coulomb, Résultats de plusieurs expériences destinées à déterminer la quantité d'action que les hommes peuvent fournir par leur travail journalier, suivant les différentes manières dont ils emploient leurs forces, Paris, 1799, rééd. in C.-A. Coulomb, Théorie des machines simples, pp. 255297.
} 
with the vault theory given by Philippe de La Hire at the beginning of the century. It did not prevent him however from using La Hire's theory at the price of changing completely all its parameters 20 .

This somewhat disconcerting eclecticism was linked to a paradoxical attitude towards calculation. On one hand, eighteenth-century engineers calculated more systematically than their predecessors. They defined more rigorously the characteristics of their designs and they used every possible tool to anticipate realization. On the other hand, they felt a growing dissatisfaction with the results they obtained. This dissatisfaction was well conveyed by the Ponts et Chaussées engineer Gaspard Riche de Prony, who was later to become member of the Académie des sciences and professor at the Ecole polytechnique, when he wrote as a student that "one should never embark about an important construction with nothing more than one's faith in a formula 21 ." At the time the scientific ideal of accuracy had begun to permeate the engineering community. The criticism addressed by a young and promising engineer such as Prony to formula had at least two meanings. First, one had to invent new methods of calculation based on scientific principles. Second, the traditional relationship between theory and practice had to change through the use of those methods. In Prony's eyes a new engineering science had thus to emerge, a science using new tools, a science leading above all to accurate predictions instead of providing general and somewhat vague indications.

20 Cf. J.-M. Delbecq, "Analyse de la stabilité des voûtes en maçonnerie de Charles Augustin Coulomb à nos jours", in Annales des Ponts et Chaussées, n ${ }^{\circ}$ spécial $150^{\mathrm{e}}$ anniversaire, $\mathrm{n}^{\circ} 19,1981$, pp. 36-43.

21 G. Riche de Prony, French essay of 1779, manuscript of the Ecole nationale des Ponts et Chaussées, carton "Concours de style et concours littéraires 1778-1812". 
As if Prony's diagnosis on existing formula needed further confirmation, the most daring structures realized during the second half of the eighteenth century, such as Perronet's bridges or Soufflot's Sainte-Geneviève church, were simply impossible to build according to the traditional engineering knowledge 22 . Faith in formula did not only lead to errors, it could also inhibit the spirit of invention. It was typical of the limits of calculation, that the first major theoretical work done by Prony was an attempt to ascertain that Perronet's bridge of Neuilly was stable 23 . Calculation thus followed realization instead of preceding it. The problems encountered by fortification could be taken as a supplementary confirmation. Among all engineering works, fortification was certainly the most rationalized. Even its most minute details were the result of calculation. This rigorous definition, that military engineers were so proud of, did not however prevent the decline of their practice. Their sophisticated calculation did not allow them to foresee the spectacular progress of artillery and the evolution of strategy following upon. On the contrary, it blinded them to the new features of the time and made them vulnerable to challenge of the Ponts et Chaussées engineers 24 .

Experiment was clearly one of the new features of the time, but its multiplication seemed to create disorder rather than a new order. Growing amounts of data were produced without fitting into any existing theoretical frame. This does not mean however that engineers inquiries had no coherence at all, rather that this coherence was not to be found on the level of their immediate results. Similarly, neither the

22 Cf. A. Picon, French architects and engineers in the age of the enlightenment, traduction anglaise de Architectes et ingénieurs au siècle des Lumières, Marseille, 1988, English translation Cambridge, Cambridge University Press, 1992.

23 G. Riche de Prony, Application de la mécanique des voûtes à la construction du pont de Neuilly, manuscript of the Ecole nationale des Ponts et Chaussées Ms 2215.

24 Cf. A. Picon, "Naissance du territoire moderne: Génies civil et militaire à la fin du XVIII ${ }^{\mathrm{e}}$ siècle", in VRBI, $\mathrm{n}^{\circ} \mathrm{XI}, 1989$, pp. C-CXIV. 
distrust in existing theories nor the few attempts made to replace them by more satisfying theoretical constructions were the most significant aspect of the engineers trend towards calculation.

\section{TOWARDS A NEW CONCEPTION OF EFFICIENCY}

To appreciate the real scope of engineering experiment, one may start from the widespread eighteenth-century conviction that sciences and arts were founded on elements. The research of more fundamental elements than proportions, elements on which architectural practice could be based, was for instance one of the major theoretical trends of architectural thought. Standing in contrast with the brevity of the article on the natural elements, the Encyclopédie devoted full pages to the "éléments des sciences". "Generally speaking, elements are the primitive parts of a whole," wrote D'Alembert in the latter article. He then observed that the elements of sciences and arts were seldom absolutely primitive and natural. Although non natural, they played a decisive role in education 25 . Sciences and arts were cumulative, they could be taught and learnt because they were at bottom combinations of elements.

For engineers, to experiment in order to create new data was to contribute to the identification of the true elements of their art, even if those elements did not fit into a comprehensive theory. The attempts made by engineers such as Coulomb or Prony to create new methods of calculation were also part of that scheme, because the notion of element applied not only to empirical data but more generally to any regularity of

25 J. le Rond D'Alembert, "Eléments des sciences", in Encyclopédie, ou dictionnaire raisonné des sciences, des arts et des métiers, Paris, Briasson, 1751-1772, vol. 5, pp. 491-497. 
nature which could be exploited by sciences and arts. Newton's inverse square law was an element of mechanics, just as was the value of the constant of gravitation.

Since elements were not the result of an absolute reduction - even the elements of the new chemistry of Lavoisier were perhaps not ultimate substances 26 - their identification was relative to man's knowledge and craft. It was man who distinguished between elements in a nature that was in fact a unifed whole ${ }^{27}$. To characterize elements, one had to take a step further: elements could be considered as such because they combined in a dynamic way. In Enlightenment culture, the notion of element was intimately associated with the notion of operation. Elements were the result of the operations of man inquiring into natural dynamism, but they also appeared in the operations of nature, in its continuous compositions and decompositions.

Many eighteenth-century engineering experiments and calculations aimed at understanding the dynamism of nature, the process which took place in its bosom, from the distribution of thrust in a structure, a distribution that could be easily assimilated to a circulation, to the flow of water or the consumption of animal and human labor force. Whereas their predecessors mainly dealt with questions of equilibrium and with the study of static structures, the engineers of the Enlightenment became obsessed with the figure of movement, with the desire to master its principles. The spectacular development of applied hydrodynamics was a consequence of this desire, as was the rediscovery of the qualities of Gothic

\footnotetext{
26 This view was for instance expressed by Fourcroy in his Eléments de chimie published in 1803.

27 If a perfect intelligence looked at nature, it would see only one principle at work, observed D'Alembert at the begining of his article "Elements des sciences".
} 
architecture by builders. What fascinated the latter in the great medieval churches was precisely the complex circulation of thrusts achieved by that type of structure 28 .

This approach of nature was a source of inspiration for the rationalization of engineering practice. Beside the natural elements involved in engineering one had to identify elementary building or manufacturing operations. Such was the path taken by Perronet to build his bridges. More generally, eighteenth-century engineers began to decompose methodically their productions into elementary parts, to think in terms of rigorously defined components and operations. Given both the weakness of tradition and the difficulty of replacing it, such a method was the best way to achieve rationalization.

Regarded as essentially dynamic, this method was very similar to the one used in the descriptions of the arts and crafts in the Encyclopédie. The convergence is not surprising, since the Encyclopedists shared the same concern for technological rationalization. In an article on the knitting machine, Diderot laid bare the principles of a satisfactory description. It was based on "a kind a analysis which consists in distributing the machine in various parts ... before assembling those parts to rebuild the entire machine $29 "$. This procedure also bore some analogy with the very general analytical method used by philosophers at the time. In his Cours d'études of 1775, Condillac stated that "analysis is the entire decomposition of an object and the

28 Cf. A. Coste, L'Architecture gothique. Lectures et interprétation d'un modèle, PHD dissertation, Grenoble, Université de Grenoble, 1996.

29 D. Diderot, "Bas", in Encyclopédie, vol. 1, pp. 98-113, on p. 98. On this crucial article, see J. Proust, "L'Article 'Bas' de Diderot", in M. Duchet and M. Jalley (eds.), Langue et langage de Leibniz. à l'Encyclopédie, Paris, 10/18, 1977, pp. 245-271. About the analytic method used by the encyclopedists, see also A. Picon, "Gestes ouvriers, opérations et processus. La Vision du travail des encyclopédistes", in Recherches sur Diderot et sur l'Encyclopédie, vol. 13, 1992, pp. 131-147. 
arranging of its components so that generation becomes both easy and understandable $30 "$.

In a culture which supposed that the origin of thought was to be found in the various sensations experienced by the subject, part of the seduction exerted by this analytical approach was linked to its strong sensationalist connotations. For scientists and philosophers, analysis was the method which explained chiefly the generation of knowledge starting from the primitive sensations. For the engineers, analysis related the physical experience of the world, the identification of its natural elements, to the most sophisticated combinations of their art. Analysis was at once the best method to identify the practical elements of engineering, and the most appropriate way to combine them in order to give birth to more complex entities such as scientific principles or design patterns.

At that point, one must observe that although quantification and mathematical calculation could be considered as the quintessence of analysis, the analytical method could very well remain purely qualitative. The eighteenth-century engineers trend towards calculation was broader than the "mathematisation" process, just as Condillac wanted analysis to be more general than mathematical reasoning.

The vision of nature embodied in their version of the analytical method led the engineers gradually to a new conception of efficiency. Whereas their predecessors of the Classical Age had seen the world as something essentially architectonic, they were now struck by the everlasting mobility and productivity of nature. In the Vitruvian tradition, efficiency was implicitly linked to an ideal arrangement of parts and means

30 E. Bonnot de Condillac, "Cours d'études pour le prince de Parme", "V. De l'Art de penser", in Euvres philosophiques de Condillac, Paris, P.U.F., 1947-1951, vol. 1, p. 769. 
ruled by proportion; it became synonym of vital change and movement. If Vitruvian efficiency was to be achieved through the use of appropriate proportions, the new type of efficiency engineers began to look for dwelt on man's capture and use of natural dynamism, a dynamism that had to be regulated for sure, but certainly not arbitrarily stopped. Beside civil engineering, eighteenth-century urbanism and territorial planning were clearly inspired by this conception. Nothing was to keep water and air from circulating freely in cities. "It is well known that the healthiest water would corrupt without the movement which maintains its purity", wrote for example Parmentier in his Dissertation sur la nature des eaux de la Seine of 1787 31. The suppression of urban ditches with their stagnant water was a consequence of that conviction. The destruction of houses built on bridges was another since those houses were supposed to prevent the renewal of atmosphere ${ }^{32}$. Understanding the natural dynamism, using it without depriving it from its vital influx was becoming a general concern as well as a practical issue for engineers.

\section{FROM NATURE TO SOCIETY}

For Condillac and his followers the purpose of analysis was not only the enhancement of rationality. I had moreover an ethical and social value, since it enabled man to free himself from illusions and prejudices. The eighteenth-century French engineers vision of a dynamic nature had social connotations as well. The principles of efficiency at

\footnotetext{
31 A.-A. Parmentier, Dissertation sur la nature des eaux de la Seine, avec quelques observations relatives aux propriétés physiques et économiques de l'eau en général, Paris, Buisson, 1787, p. 21.

32 On these major preoccupations of eighteenth-century urbanism, see, for example, B. BarretKriegel, B. Beguin, B. Fortier, D. Friedmann, A. Monchablon, La Politique de l'espace parisien à la fin de l'Ancien Régime, Paris, 1975; J.-C. Perrot, Genèse d'une ville moderne; A. Guillerme, Les Temps de l'eau. La cité, l'eau et les techniques, Seyssel, Champ Vallon, 1983; B. Lepetit, Les Villes
} 
work in the natural world could indeed apply to Old Regime society which was blocked in many ways. Following the arguments of the first economists, and their famous "laissez faire-laissez passer", engineers were deeply convinced that the development of trade was part of the answer. Men, goods and ideas were to circulate freely in order to regenerate society, just as the best way to purify water was to make it flow.

Employed by the State, Fortification or Ponts et Chaussées engineers were especially aware of the social meaning of their action. "It is the engineer who is in charge of the designs meant to provide happiness 33 ," wrote for example one Ponts et Chaussées engineer convinced of the importance of transport infrastructures for the promotion of public welfare. But how to distinguish between designs which provided happiness and others ? In the case of the Ponts et Chaussées, the question was even more crucial because roads were built using peasants' forced labor. If roads were adding to public welfare in the long term, their immediate impact was rather a burden to the people.

In this context State engineers began to preoccupy themselves with the possible quantification of utility. The first attempts were rather unsophisticated. Given the perspective of a new infrastructure, one could estimate the cost of transportation on the existing roads, rivers and canals, and compare it with what it would be using the planed infrastructure. Such a method was employed for instance by Perronet in a memoir devoted to the construction of the Canal de Bourgogne ${ }^{34}$. If his economic

dans la France moderne (1740-1840), Paris, Albin Michel, 1988; A. Picon, French architects and engineers.

33. P. Planier, French essay of 1779, manuscript of the Ecole nationale des Ponts et Chaussées, Carton "Concours de style et concours littéraires 1778-1812".

34 J.-R. Perronet, Description des projets et de la construction des ponts de Neuilli, de Mantes, d'Orléans, de Louis XVI, etc.; du projet du canal de Bourgogne (...) et de celui de la conduite des 
calculation itself was rather primitive, two at least of Perronet's underlying assumptions were fundamental. The first one was the hypothesis of a perfect continuity between engineering and economics. The second assumption was that analytic methods applied to both. The investigation of technological elements and operations found a natural extension in the identification of elementary costs and profits.

Those two assumptions were also present in the discussion of more general problems such as the comparative advantages of roads and canals or the possible replacement of forced labor by a combined system of taxes and maintenance by appointed workers. Who was to pay for a new infrastructure, the owners of the lands situated nearby or the people using the infrastructure and damaging it ? Was the state supposed to raise taxes directly or should the necessary maintenance costs be provided by tolls ? Was each new infrastructure to achieve financial equilibrium or was it more interesting to consider transfers permitting the construction of non-profitable though necessary equipment ? From the 1760's on, all these questions were raised in an abundant production of articles, memoirs and even books written by engineers. Authors such as the artillery officer François de Pommereul or the Ponts et Chaussées engineer Nicolas Defer were among the most fierce polemicists on such issues 35 .

Several new key notions and ideas permeated this literature. The first was the notion of network. Engineering infrastructures such as bridges, roads and canals, were no

eaux de l'Yvette et de Bièvre à Paris, Paris, 1782-1783, new edition Paris, Didot fils aîné, Jombert jeune, 1788, pp. 344-389.

35 See for instance F. Pommereul, Des Chemins, et des moyens les moins onéreux au peuple et à l'Etat de les construire et de les entretenir, 1781; N. Defer, La Science des canaux navigables ou théorie générale de leur construction, Paris, l'auteur, 1786. On the general history of economic calculation, read F. Etner, Histoire du calcul économique, Paris, Economica, 1987. More details about the debates linked to the forced labor can be found in J.-M. Goger, La politique routière en France de 1716 à 1815, PHD dissertation, Paris, Ecole des hautes études en sciences sociales, 1988. 
longer considered as isolated monuments; they had to be connected in order to become parts of more general systems of transportation. Another important idea was that the engineer had to think in terms of process and regulation. His mission was not only to design and supervise realization; it extended from the first drawings to the maintenance after completion. The best illustration of this new perspective was the type of road imagined by the Ponts et Chaussées engineer Jérôme Trésaguet in the 1760's. Working for Turgot who was at the time intendant of Limoges, Trésaguet designed a system which included maintenance by skilled workers. Its details, such as the use of a coat of small stones were inseparable from the choices made for maintenance. Those choices were themselves consequences of the political decision made by Turgot to suppress forced labor in his district of Limoges 36.

Trésaguet's contribution was thus an especially striking demonstration that engineering and political economy had strong practical links. Going even further, some engineers began to consider the use of a common scientific formalism for those two branches of knowledge and practice. The Ponts et Chaussées engineer AchilleNicolas Isnard tried to redefine economics from this perspective in his Traité des richesses published in 1781. According to Isnard, economics had to become the "science of man", a science seen as a kind of mechanics based on the rational decomposition and recomposition of individual interests 37 . There again, analysis

36 P.-M.-J. Trésaguet, Mémoire sur la construction et l'entretien des chemins faits en rachat de corvée dans la généralité de Limoges, 1775, manuscript of the Ecole nationale des Ponts et Chaussées Ms 1886. On Trésaguet's importance in the history of road techniques and economics, see J.-M. Goger, op. cit., as well as M. Yvon, "Pierre-Marie-Jérôme Trésaguet, ingénieur des Ponts et Chaussées (1716-1796) créateur d'une méthode rationnelle pour construire et entretenir les chaussées empierrées au XVIIIe siècle", in Les Routes du sud de la France de l'Antiquité à l'époque contemporaine, Paris, C.T.H.S., 1985pp. 295-318.

37 On Isnard's work, see J.-C. Perrot, "Premiers aspects de l'équilibre dans la pensée économique française", in Annales Economies Sociétés Civilisations, 1983, n 5, pp. 1058-1074; J.-C. Perrot, Une Histoire intellectuelle de l'économie politique. 
appeared as a generic method applying to economics as it applied already to engineering.

Isnard theoretical ambition was far more developed for sure that what suited an engineer. Because of his book, he had some trouble with Perronet who was then at the head of the Ponts et Chaussées administration and did not like young engineers to particularize themselves. But Isnard shared nevertheless with numerous of his fellow engineers the conviction that the social dynamism could be someday described, understood and even controlled, just as the natural one was to be in the meantime. Despite his objections against Isnard's Traité des richesses, Perronet had led the way with the strict control he had exercised on the workers employed on his bridges sites. To reinforce his control, Perronet had even invented machines enabling him to pay workers employed at water draining and pile driving after the number of revolutions or strokes carried out, rather than after the time spent on the site ${ }^{38}$. Around the 1780's, Ponts et Chaussées engineers began to design harbors and arsenals as elaborate systems of circulation and storage for men and goods, systems that were prototypes for an entirely rationalized and controlled urban space 39.

Just as these plans were impracticable, most of engineers' economic calculations had almost no impact. Two reasons at least accounted for this ineffectiveness. Beside the weight of tradition, one has to take into account the highly political character of decisions regarding territorial planning. Until the first half of the nineteenth century, it was certainly not economic calculation that dictated the construction of a fortress or even a road, but rather a mixture of common sense and political opportunism. Some

38 J.-R. Perronet, Machines pour faire les épuisements à la tâche, 1752, manuscript of the Ecole nationale des Ponts et Chaussées, Ms 2125.

39 That type of design has bee analysed in B. Fortier, A. Demangeon, Les Vaisseaux et les villes, Bruxelles, Liège, Mardaga, 1978. 
roads had simply to be build because of the evident need of trade, others were the result of complex negotiations between the various authorities involved.

Why did the engineers calculate then, putting aside their interest in intellectual speculation? The criticisms of an elite such as the Physiocrats against the used of forced labor gave the first incentive to speculate on the utility of transportation means. Awed by the opposition of people ranked among the leaders of emerging public opinion, State engineers had to justify themselves. A more general need for justification can be deduced from the frequent comparison between the engineer and the judge that appeared at the end of the eighteenth century. In his Memoire sur la construction des chemins published in 1782, the Ponts et Chaussées engineer François-Michel Lecreulx wrote for instance that "engineering bears a greater analogy to the legal profession than to the military $40 "$. Three years later, the students of the Ecole des Ponts were asked to develop the following argument for a French essay: "which is the more useful, a great soldier or a virtuous judge?" For the students as well as for the trained engineers, the judge was without any doubt superior to the soldier, because he had to put aside his own interest for the sake of the public, an attitude far more demanding than the sole physical courage. Having to decide which were the most useful designs, the engineer responsibility appeared very similar indeed to the judge's one.

Through the comparison between engineering and justice, a concern for impartiality expressed itself. Calculation could play a role in this perspective, since figures and formula transcended prejudices. Revealing was in this respect the piece of advice given by Lecreux to the young engineers in his Mémoire sur la construction des chemins: stick to the straight line as far as possible, so that your roads designs will not 
be attacked by land owners. Like geometry, calculation could give evidence of the engineer's impartiality.

Impartiality is not to be confused with objectivity — who would seriously believe in a scientifically administered justice ? The eighteenth-century French State engineers did not intend to speak in the name of nature; they wanted rather to be the impartial promoters of a more rational relationship between man and nature. There was of course an implicit violence in their claim for impartiality. Though often ineffective, calculation represented in their eyes one step in the direction of power and respect.

During the first decades of the nineteenth century, the interest developed by the engineers in natural dynamism as well as their analytical approach of it provided the background for the introduction of calculus in engineering. Calculus not only enabled a thorough description of movement and flux; in disciplines such as strength of materials or hydrodynamics, it brought almost to perfection the method of decomposition/recomposition ${ }^{41}$. The close relation that was maintained between engineering and economic calculation represented another legacy of the Enlightenment. But it was above all the connection between efficiency, impartiality and calculation that was to remain a strong ideological characteristic of the French technological elites.

40 F.-M. Lecreulx, Mémoire sur la construction des chemins, 1782, p. 156.

${ }^{41} \mathrm{Cf}$. A. Picon, L'Invention de l'ingénieur moderne. 